Transactions of the American Fisheries Society, 2005, v. 134, n. 3, p. 607-619. ISSN: (Print 0002-8487) (Online 1548-8659)

DOI: $10.1577 /$ T04-094.1

http://www.fisheries.org

http://afsjournals.org/loi/fitr

http://afsjournals.org/doi/pdf/10.1577/T04-094.1

(C) Copyright by the American Fisheries Society 2005 


\title{
Testing for Evidence of Maternal Effects among Individuals and Populations of White Crappie
}

\author{
David B. Bunnell, ${ }^{* 1}$ Matthew A. Scantland, ${ }^{2}$ and Roy A. Stein \\ Aquatic Ecology Laboratory, Department of Evolution, Ecology, and \\ Organismal Biology, Ohio State University, \\ 1314 Kinnear Road, Columbus, Ohio 43212-1156, USA
}

\begin{abstract}
For an increasing number of species, maternal characteristics have been correlated with the characteristics of their eggs or larvae at the individual level. Documenting these maternal effects at the population level, however, is uncommon. For white crappies Pomoxis annularis, we evaluated whether individual maternal effects on eggs existed and then explored whether incorporating maternal effects explained additional variation in recruitment, a population-level response. Individual egg quality (measured as ovary energy density) increased with maternal length among individuals from seven Ohio reservoirs in 1999 and three in 2000. Among these same individuals, egg quality increased with maternal condition factor (measured as residual wet mass for a given length) in 1999 but not in 2000. In 2000 we estimated somatic energy density, an improved measure of condition; egg quality increased with somatic energy density, but somatic energy density was also strongly correlated with maternal length. Hence, we could not determine whether maternal length or condition was the primary factor influencing white crappie egg quality. Across seven populations, the relative population fecundity (i.e., stock size) of the 1999 year-class was unable to explain the variation in recruitment to age 2 (Ricker model $r^{2}=0.04$ and Beverton and Holt model $r^{2}=0.02$ ). Mean ovary energy density (i.e., egg quality), however, was unable to explain additional recruitment variability in either model. Hence, we documented evidence of maternal effects on individual ovaries but not on population-level recruitment. Nonetheless, we recommend that future studies seeking to understand white crappie recruitment continue to consider maternal effects as a potential factor, especially those studies that may have greater sample sizes at the population level and, in turn, a greater probability of documenting a population-level effect.
\end{abstract}

For several marine and freshwater fish taxa, the phenotype of individual mothers correlates with characteristics of her eggs and offspring. Specific examples of these so-called maternal effects include her physiological condition or size influencing the quantity or quality of her eggs (e.g., Kjesbu et al. 1991), her egg's hatching success (e.g., Laine and Rajasilta 1999), and the viability of her larvae (e.g., Marteinsdottir and Steinarsson 1998). Since observing these effects among individuals, researchers have begun attempting to measure maternal effects at the population level, but only a few studies have uncovered linkages. In one, mean length of age- 4 haddock Melanogrammus aeglefinus was positively related to the abundance of age1 recruits produced on the Scotian Shelf (Marshall and Frank 1999), and in another, condition (mea-

\footnotetext{
* Corresponding author: dbunnell@usgs.gov

${ }^{1}$ Present address: U.S. Geological Survey, Great Lakes Science Center, 1451 Green Road, Ann Arbor, Michigan 48105, USA.

2 Present address: Innova Partners, 1177 Olentangy River Road, Columbus, Ohio 43212-3117, USA.
}

Received June 3, 2004; accepted October 29, 2004 Published online May 5, 2005 sured as an index of liver size) of a spawning population Atlantic cod Gadus morhua in the Barents Sea was positively related to recruitment to age 3 (Marshall et al. 1999). Hence, these studies suggest that maternal effects, which are known to influence characteristics of eggs and larvae, also may have demographic consequences well beyond the larval stage and even beyond age 1 .

For maternal size or condition to influence recruitment to the fishery, the mechanism must include maternal effects operating through the ovary. Populations composed of females of large size or of excellent physiological condition may be more fecund or produce higher quality eggs (or both) than populations composed of females of small size or of poor condition. These hypotheses are supported by previous studies on individual females. First, females in good condition have been associated with higher fecundity (Kjesbu et al. 1991; Marshall et al. 1999) and a higher hatching success rate (Laine and Rajasilta 1999) than females in poor condition. Second, females in good condition or of large size have been associated with eggs that are larger (Beacham and Murray 1985; Kjesbu 1989; Chambers and Waiwood 1996; 
Johnston and Leggett 2002) or more energetically dense (Ouellet et al. 2001) than females in poor condition or of small size. In turn, at the population level, higher fecundity may lead to higher larval production. Similarly, higher egg quality (i.e., more yolk) could increase the hatching success or increase larval survival by reducing the probability of starvation; either of these mechanisms also could increase larval production.

Our primary goal was to understand how both quantity and quality of eggs influence recruitment of white crappie to age 2 . To achieve this goal, we first sought to measure maternal effects on the ovary at the individual level by asking (1) do maternal length and condition influence the quality of eggs produced, as measured by ovary energy density, and (2) does maternal condition influence the quantity of eggs produced, when the effects of maternal length are removed? After demonstrating maternal effects, we then used conventional stockrecruit models to determine whether recruitment to age 2 was influenced by population fecundity. Finally, we determined whether the residuals from predicted recruitment for a given level of population fecundity were positively related to the ovary quality of fishes from the population. Hence, we sought to determine whether a measure of ovary quality enhanced our understanding of recruitment variability at the population level.

We evaluated these individual-level and population-level responses for white crappie $\mathrm{Po}$ moxis annularis, a popular North American freshwater sport fish. Across North America, recruitment of white crappie and its congener, black crappie Pomoxis nigromaculatus, can be highly variable (Beam 1983; Colvin 1991, McDonough and Buchanan 1991; Sammons and Bettoli 1998). Recent evidence suggests that year-class strength may be set fairly early in life, which implies that maternal characteristics may be important. The strongest predictors of recruitment have been hydrological factors in the months before spawning (Maceina and Stimpert 1998; Maceina 2003) and density of larvae (Sammons and Bettoli 1998). In addition, adult biomass has explained up to $44 \%$ of the variation in recruitment with Ricker stockrecruit models (Allen and Miranda 1998). We hypothesized that recruitment of white crappies in Ohio reservoirs was related to the size of the spawning stock and that consideration of maternal effects would explain additional recruitment variability.
TABLE 1.-Characteristics of seven Ohio study reservoirs selected for studying maternal effects among white crappies. Percent composition is the mean percentage of adult white crappies in the total number of black and white crappies collected in autumn trap-netting, 1998-2001.

\begin{tabular}{lcccc}
\hline \multicolumn{1}{c}{ Reservoir } & Latitude & $\begin{array}{c}\text { Mean } \\
\text { depth }(\mathrm{m})\end{array}$ & $\begin{array}{c}\text { Surface } \\
\text { area }\left(\mathrm{km}^{2}\right)\end{array}$ & $\begin{array}{c}\text { Percent } \\
\text { composition }\end{array}$ \\
\hline Acton & $39^{\circ} 33^{\prime}$ & 3.9 & 2.5 & 100.0 \\
Alum Creek & $40^{\circ} 11^{\prime}$ & 7.3 & 13.7 & 65.0 \\
Berlin & $41^{\circ} 02^{\prime}$ & 4.5 & 14.8 & 68.8 \\
Burr Oak & $39^{\circ} 32^{\prime}$ & 4.5 & 2.7 & 98.2 \\
Caesar Creek & $39^{\circ} 28^{\prime}$ & 11.6 & 11.5 & 84.9 \\
LaDue & $41^{\circ} 24^{\prime}$ & 3.7 & 6.1 & 88.9 \\
Pleasant Hill & $40^{\circ} 37^{\prime}$ & 4.8 & 3.4 & 97.4 \\
\hline
\end{tabular}

\section{Methods}

Study sites.-We conducted our study in seven Ohio reservoirs that varied in density of white crappies, so that we could evaluate whether characteristics of the adult population influenced recruitment success. Black crappies co-occurred with white crappies in six of these reservoirs, but white crappies predominated in each (Table 1). Reservoir morphology was generally similar, except for Caesar Creek Reservoir, which is nearly twice as deep as most of the other ones.

Autumn sampling of adult and age-2 white crappies.-Autumn sampling provided estimates of the relative abundance of adults and recruits (age 2). Fishes were sampled in all seven reservoirs with Missouri-style trap nets (Colvin and Vasey 1986; $1.27-\mathrm{cm}$ mesh, two rectangular frames $[0.91 \times$ $1.82 \mathrm{~m}$ ], four $0.76-\mathrm{m}$ diameter hoops, with a 21.3$\mathrm{m}$ lead). Autumn sampling (October 12 to November 11) in 1998 provided an index of the relative abundance (i.e., catch per effort [CPE] or number/ net-night) of adults that would produce the 1999 year-class. We considered adults to be fish longer than $18 \mathrm{~cm}$ total length (TL) because every white crappie of this size that we sampled in spring was mature, as indicated by large, conspicuous gonads (D. B. Bunnell, unpublished data). Autumn sampling (October 9 to October 26) in 2001 provided an index of recruitment for age-2 white crappies from that 1999 year-class. We set age 2 as our index of recruitment because age-2 white crappies are large enough to be fully vulnerable to our trap nets (sensu Colvin and Vasey 1986).

Each autumn, 10 nets were set at fixed locations within each reservoir over 4 nights (i.e., 40 netnights). Net locations were stratified across three major areas of the reservoir (upper reach, middle reach, and lower reach near the dam), and within each reach, we selected sites 2-4 m deep on the 
slope of the channel, through which white crappies move during autumn. All white crappies collected were measured $(\mathrm{mm}, \mathrm{TL})$. We measured the wet mass $(0.5 \mathrm{~g})$ of up to 10 fish per centimeter lengthclass. We used otoliths to estimate ages of fish of a given size in each population. When white crappies were abundant (i.e., more than 200 adults sampled over the course of the week), all fish from at least $50 \%$ of the nets each day (selected randomly before sampling) were harvested for age estimation. In reservoirs with lower densities of adults, we harvested fish for otoliths from all nets to increase our sample size. On average, we aged $209(\mathrm{SD}=48.4)$ white crappies greater than 13 $\mathrm{cm}$ TL per reservoir. Fish not harvested for aging were released after their left pectoral fin was clipped to prevent recaptured fish from being recounted if recaptured.

The relative abundance or CPE of age- 2 white crappies was estimated using a length-age key (DeVries and Frie 1996) based on otolith-derived age estimates. Whole otoliths were immersed in glycerol and annular rings were counted under 10$20 \times$ magnification. Whole otoliths from older fish were cracked to expose the cross section that facilitated aging. For each reservoir, the proportion of ages that composed each centimeter length-class was applied to the population length distribution to estimate ages of all captured fish. For each reservoir, we estimated the mean CPE of age- 2 white crappies across net-nights.

Spring sampling of spawning adults.-To explore relationships between individual maternal characteristics and the quality and quantity of her eggs and to generate population-level estimates of egg quantity and quality, we collected ovaries of prespawning white crappies with trap nets from seven reservoirs during April 19-28, 1999. During this period, water temperatures ranged $9-14^{\circ} \mathrm{C}$. From these ovaries, we estimated fecundity (egg quantity) and energy density (egg quality). In each reservoir, four to six trap nets (same as used in autumn) were set for 3-4 nights to collect at least four female fish per centimeter length-class to ensure a broad distribution of ages and lengths. Ova never were expelled during handling, which indicated that fish had not yet begun spawning. Because white crappie reproduction is probably regulated by photoperiod (Siefert 1968), we assumed that populations across these seven reservoirs were at similar developmental stages. Upon capture, white crappies were placed on ice, returned to the laboratory to determine sex, weight $(\mathrm{g})$, and TL $(\mathrm{mm})$. Fish in each centimeter length-class were alternately preserved for either fecundity or ovary energy density estimation. Ovaries preserved for fecundity estimates were dissected from the soma, weighed $(0.1 \mathrm{~g})$ and placed in $5 \%$ buffered formalin for at least 6 months. Ovaries preserved for energy density estimation were not removed, and the intact fish was frozen in water.

We sought to evaluate how maternal length and condition influenced ovary energy density and how maternal condition influenced fecundity. Many of the studies exploring the effects of maternal condition use a condition factor based on relative wet mass (e.g., Chambers and Waiwood 1996; Blanchard et al. 2003), an approach we followed with the 1999 samples. However, we also sampled a subset (i.e., Alum Creek, Caesar Creek, Pleasant Hill) of the 1999 reservoirs during April 18-21, 2000. During this period, water temperatures ranged $10-13^{\circ} \mathrm{C}$. With the fish captured in 2000, we characterized their condition based on somatic energy density and their condition factor. We viewed somatic energy density as a better metric of maternal condition than a condition factor based on wet mass. Wet mass of a fish may not fully reflect its physiological condition because fish tissue with low lipid concentrations tends to have high water content (Flath and Diana 1985). We expect that tissue with high lipid content also will have a higher energy density (sensu Flath and Diana 1985) because of the high energy density of lipids, which have $40 \%$ more energy than proteins and 56\% more energy than carbohydrates (Phillips 1969).

To calculate a length-weight based estimate of condition factor, we chose a residual approach rather than Fulton's $K\left(=100 \cdot W / L^{3}\right)$ because we wanted to eliminate any relationship between condition and fish size. For both 1999 and 2000, we first estimated the relationship between somatic mass (i.e., without ovary mass), $M$, and length, $L$, as $M=a L^{b}$ for all white crappies sampled in each year. We estimated the parameters $a$ and $b$ by $\log _{e}$ transforming mass and length, and by using linear regression $\log _{e} M=\log _{e} a+b \cdot \log _{e} L$. Parameter $b$ equaled the slope of the regression. Parameter $a$ was calculated by taking the antilog of $\log _{e} a$ (i.e., the intercept of the regression) and, then, by correcting for the bias by multiplying it by its correction factor: $e^{\mathrm{MSE} / 2}$, where MSE is mean square error of the regression (Sprugel 1983). Condition factor was the residual mass, calculated as the difference between observed and predicted somatic mass for a fish of a given length.

To estimate somatic energy density for wet mass 
$(\mathrm{kJ} / \mathrm{g})$ in 2000 , we thawed the frozen fish at room temperature and removed the contents of the stomach, intestines, and ovaries. Somatic tissue was dried following Rand et al. (1994). Upon reaching a constant mass, it was ground with dry ice (via a Retsch ZM 100 electric tissue grinder) and then dried again for $3 \mathrm{~d}$ at $65-70^{\circ} \mathrm{C}$ and formed into at least two composite pellets (each about $1 \mathrm{~g}$ ) per fish. To estimate somatic energy density (dry mass), two pellets from each fish were ignited in an oxygen calorimeter (Parr Instrument Co., Model 1341), but when the two estimates differed by more than $400 \mathrm{~kJ} / \mathrm{g}$ (a difference of about $2 \%$ ), a third pellet was ignited. This enabled somatic energy density to be calculated as the mean of the two pellets that differed by less than $2 \%$. Initial energy density was corrected for liberated $\mathrm{H}_{2} \mathrm{SO}_{4}$ (using a base titration), sulfur content (using a fixed average), and fuse combustion (Parr Instrument Co. 1993). We converted dry mass somatic energy density to wet mass tissue by using the total dry : wet mass ratio of the somatic tissue.

To characterize ovary quality, we estimated energy density $(\mathrm{kJ} / \mathrm{g}$ ) of whole ovaries (wet mass) from 109 females from the seven reservoirs in 1999 and 46 females from the three reservoirs in 2000. Ovary energy density was estimated with the same methods used for estimated energy density of somatic tissue, except that we used a microcalorimeter (Parr Instruments model 1425), which accommodated 0.1 -g samples of dried ovary tissue.

To estimate fecundity, we used ovaries from 76 female white crappies from the seven reservoirs in 1999. For each reservoir, we estimated fecundity from 7 to 13 fish, typically one per centimeter length-class. We considered eggs to be mature if they were completely opaque and full of yolk (diameter range $=0.4-1.0 \mathrm{~mm}$ ). We counted mature eggs in three 4-mm-diameter cores in both ovarian lobes (Henderson and Nepszy 1994). After counting, the individual cores and the remaining ovary were dried at $60^{\circ} \mathrm{C}$ to a constant dry mass, from which we estimated egg density (eggs/g) for each core and mean egg density across cores. We multiplied mean egg density by the total dry mass of the ovary (remaining ovary + mass of six individual cores) to estimate fecundity for each fish.

Analysis of individual maternal effects.-Using a general linear model (Proc GLM, SAS Institute 1999), reservoir as a class variable, and individual fish as the sampling unit, we determined whether ovary energy density was influenced by (1) maternal condition (condition factor in 1999 and so- matic energy density in 2000), (2) maternal length, (3) the reservoir from which it was sampled, and (4) the potential interactions (length $\times$ condition interaction, reservoir $\times$ condition interaction, reservoir $\times$ length interaction). For this and subsequent analyses, we set $\alpha=0.05$. In terms of fecundity, we used nonlinear regression (Proc NLIN, SAS Institute 1999) to calculate the predicted fecundity for a fish of given length via the relationship $F=a L^{b}$, where $F$ is total number of mature eggs and $L$ is fish length $(\mathrm{cm})$. We then calculated residual fecundity for each fish, as the difference between the observed and predicted fecundity. With the effect of fish length removed, we used a general linear model, reservoir as a class variable, and individual fish as the sampling unit to evaluate whether residual fecundity was influenced by maternal condition, the reservoir from which it was sampled, and the reservoir $\times$ condition interaction.

Analysis of population maternal effects.-At the population level, we evaluated whether egg quality could explain additional variation in the stockrecruit relationship for the 1999 white crappie year-class, where stock size was based on fecundity, which is preferred to measures of stock size based on adult biomass or abundance (Hilborn and Walters 1992). To characterize quality of eggs at the population level, we used the least-squares mean ovary energy density for each reservoir, which accounted for differences in maternal characteristics (i.e., maternal condition and length) across reservoirs. To characterize relative population fecundity, we considered both the average fecundity of individuals and the relative number (i.e., CPE) of adults. We estimated relative population fecundity, $S$, as

$$
S=\sum_{i=18}^{n} F_{i} \times A_{i}
$$

where, for centimeter length-class $i, F_{i}$ is the predicted fecundity of 1999 white crappies and $A_{i}$ is the number of white crappies sampled during autumn 1998. Unfortunately, predicted fecundity estimates were derived from all individuals from all reservoirs pooled together, rather than reservoirspecific length fecundity relationships. In three of the seven reservoirs, we caught larger sizes of adults in the autumn than in the spring, and we did not want to extrapolate fecundity within a reservoir. We made two assumptions in calculating relative population fecundity. First, we assumed that the number of adults sampled in our trap nets was representative of the number of females in 
each reservoir. A 1.2 female : 1.0 male ratio estimated from Pleasant Hill reservoir in 2001 provided some support for this assumption. Second, we assumed that the number of adults sampled in autumn was representative of the number of adults that spawned the following spring (i.e., that adult overwinter mortality did not differ across reservoirs).

We hypothesized that recruitment to age 2 and relative population fecundity would be related through two conventional stock-recruit models: (1) Ricker, $R=S e^{a(1-S / b)} e^{\varepsilon}$, and (2) Beverton and Holt, $R=a S e^{\epsilon} /(b+S)$, where $R$ is the CPE of age- 2 recruits, $S$ is the predicted population fecundity (in millions of eggs), and $\varepsilon$ is the $\log _{e}$ error term. For each model, we followed Hilborn and Walters (1992) to transform the Ricker and Beverton and Holt equations

$$
\begin{aligned}
& \log _{e} \frac{R}{S}=a-\frac{a}{b} S+\varepsilon \quad \text { and } \\
& \log _{e} R=\log _{e}\left(\frac{a S}{b+S}\right)+\varepsilon
\end{aligned}
$$

into a form that could be solved using least squares regression. To incorporate the error into each model (which yields the average number of recruits for a given level of spawning stock), some of the parameters in each model were modified. In the Ricker, $a^{\prime}=a+\sigma^{2} / 2$, where $\sigma^{2}$ equals the mean square error from the model, and $b^{\prime}=\left(a^{\prime} / a\right) \cdot b$ (Hilborn and Walters 1992). In the Beverton and Holt, $a^{\prime}=a e^{\sigma^{2 / 2}}$ (Hilborn and Walters 1992). Using these modified parameters, we calculated the residual recruitment for each population, as the difference between the observed and predicted recruitment for a given relative population fecundity. Finally, we used Pearson's correlation to determine whether mean ovary quality was positively related to recruitment residual across the seven populations.

\section{Results}

\section{Individual Maternal Effects}

For the 1999 year-class, nearly $78 \%$ of the variation in ovary energy density was explained by maternal condition (condition factor), length, reservoir, and the three possible interaction terms. Ovary energy density increased with both maternal length $\left(F_{1,99}=98.36 ; P<0.0001\right.$; Figure 1a) and maternal condition $\left(F_{1,99}=20.00 ; P<0.0001\right.$; Figure 1b). The interaction between maternal length and condition $\left(F_{1,99}=15.52 ; P=0.0002\right)$ also was significant, indicating that fish of similar size but different condition (or vice versa) had different ovary energy densities. Ovary quality also differed between reservoirs $\left(F_{6,99}=7.68 ; P\right.$ $<0.0001)$. The effect of maternal length and maternal condition on ovary energy density differed across reservoirs, as indicated by the significant interaction terms (reservoir $\times$ length interaction: $F_{6,99}=7.55 ; P<0.0001$; reservoir $\times$ condition interaction: $F_{6,99}=3.07 ; P=0.009$ ). Overall, the quality of the eggs increased with maternal length and condition, but patterns differed across reservoirs; maternal length appeared to have the greater impact (Figure 1a, b).

To confirm the effect of maternal condition on ovary quality via a potentially more appropriate measure, we conducted the same analyses on ovaries from Alum Creek, Caesar Creek, and Pleasant Hill reservoirs in 2000 but used somatic energy density rather than the condition factor. In 2000, ovary energy density once again increased with maternal length $\left(F_{1,40}=7.56, P=0.009\right.$, Figure 1c) and differed among reservoirs $\left(F_{2,40}=9.82\right.$; $P=0.003)$. The effects of maternal condition were more difficult to interpret. Indeed, somatic energy density was marginally significant in the model $\left(F_{1,40}=3.42, P=0.07\right.$, Figure $\left.1 \mathrm{e}\right)$, as was the interaction between maternal length and somatic energy density $\left(F_{1,40}=3.05 ; P=0.09\right)$. These results were complicated, however, by the strong positive correlation between somatic energy density and maternal length (Pearson correlation: $r=$ $0.73, P<0.0001$ ), which indicated that larger females also tended to have a higher somatic energy density. When we ran the same analyses with condition factor, rather than with somatic energy density, more of the variance was explained by maternal length $\left(F_{1,40}=139.5 ; P<0.0001\right)$ than by condition $\left(F_{1,40}=1.30 ; P=0.26\right.$; Figure $\left.1 \mathrm{~d}\right)$, as we found in 1999. In addition, we note that condition factor and maternal length were not positively correlated in $1999(r=-0.03, P=0.78)$ or in $2000(r=0.21, P=0.17)$, as expected. Using condition factor alone, we would have concluded that maternal length influenced ovary energy density more than maternal condition in both years (but more in 1999 than in 2000). By estimating maternal condition with somatic energy density in 2000 , however, we realized that the covarying relationship between maternal condition and length makes discriminating maternal effects on white crappie ovary quality a more complex question.

Mean ovary energy density differed across reservoirs in both years. In 1999, Tukey-Krameradjusted multiple comparisons of least-squares 

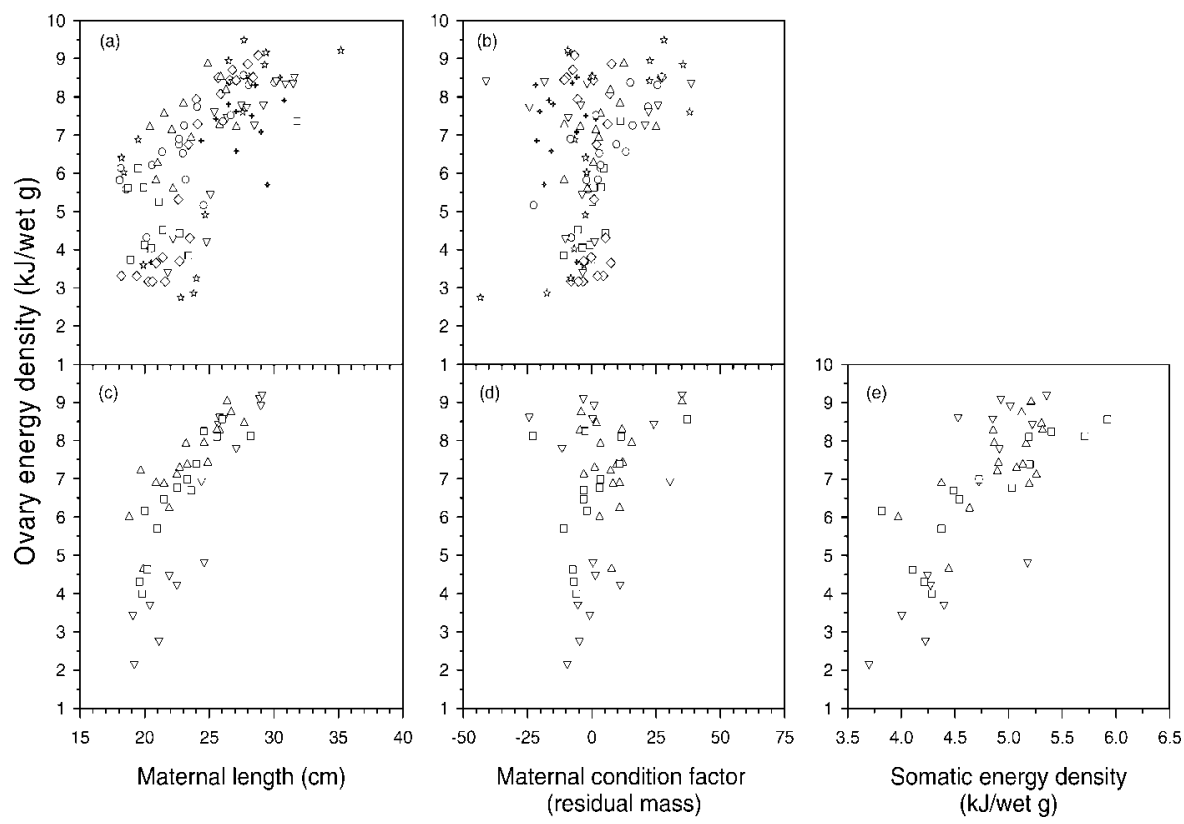

FIGURE 1.-Ovary (wet weight) energy density of prespawning white crappies collected from seven Ohio reservoirs versus maternal length in (a) 1999 and (c) 2000, maternal condition in (b) 1999 and (d) 2000, and (e) somatic energy density in 2000. Symbols are as follows: circles, Acton; inverted triangles, Alum Creek; crosses, Berlin; stars, Burr Oak; upright triangles, Caesar Creek; diamonds, LaDue; and squares, Pleasant Hill. In April 1999 (two top panels), all seven reservoirs were sampled; in 2000 (three bottom panels) just three of the seven were sampled, namely, Alum Creek, Caesar Creek, and Pleasant Hill. For presentational simplicity, the following points, which entailed extreme condition factors, were not included in panel (b): Burr Oak (-89.0, 10.0), Acton (90.5, 7.3), and Acton (97.2, 8.6).

means revealed ovaries from Caesar Creek (which had the highest ranked mean) to be more energetically dense than those from Alum Creek and Pleasant Hill reservoirs (which had the lowest ranked means). Ovaries from Berlin, LaDue, Burr Oak, and Acton reservoirs were similar to those from Caesar Creek, Alum Creek, and Pleasant Hill reservoirs. As in 1999, ovaries from Caesar Creek Reservoir had the highest ranked mean energy density in 2000, although it was not different from the mean of ovaries from Pleasant Hill Reservoir. Ovaries from both Caesar Creek and Pleasant Hill reservoirs had a higher mean energy density than ovaries from Alum Creek Reservoir in 2000. Among the reservoirs sampled both years, ovaries from Caesar Creek had a consistently high mean energy density, whereas ovaries from Alum Creek had a consistently low one.

White crappie fecundity increased exponentially with total length when fish from all reservoirs were pooled (fecundity $=0.048 L^{4.30} ; F_{2,74}=390.4, P$ $<0.0001, r^{2}=0.91$; Figure 2a). Residual fecundity, however, was not influenced by maternal condition, measured as condition factor $\left(F_{1,62}=0.69\right.$,
$P=0.41$; Figure $2 \mathrm{~b}$ ), nor by the interaction of reservoir and maternal condition $\left(F_{6,62}=0.29, P\right.$ $=0.94)$, even though differences in mean residual fecundity existed across reservoirs $\left(F_{6,62}=2.47\right.$, $P=0.03)$. White crappies from Burr Oak Reservoir had a significantly lower mean residual fecundity than those from Caesar Creek and Berlin reservoirs (Tukey-Kramer multiple comparisons).

\section{Population Maternal Effects}

Differences in the relative abundance and size distributions of white crappie adults (Figure 3 ) that spawned the 1999 year-class accounted for differences in relative population fecundity. Adult white crappies in LaDue Reservoir were predicted to produce the highest number of eggs, followed by Pleasant Hill Reservoir, even though adult abundance in LaDue Reservoir was about $44 \%$ of Pleasant Hill Reservoir. Adults in Acton Reservoir were predicted to produce the third highest number of eggs among the reservoirs, followed by adults in Berlin, Caesar Creek, and Alum Creek reservoirs. White crappies in Burr Oak Reservoir were predicted to produce the fewest number of eggs be- 

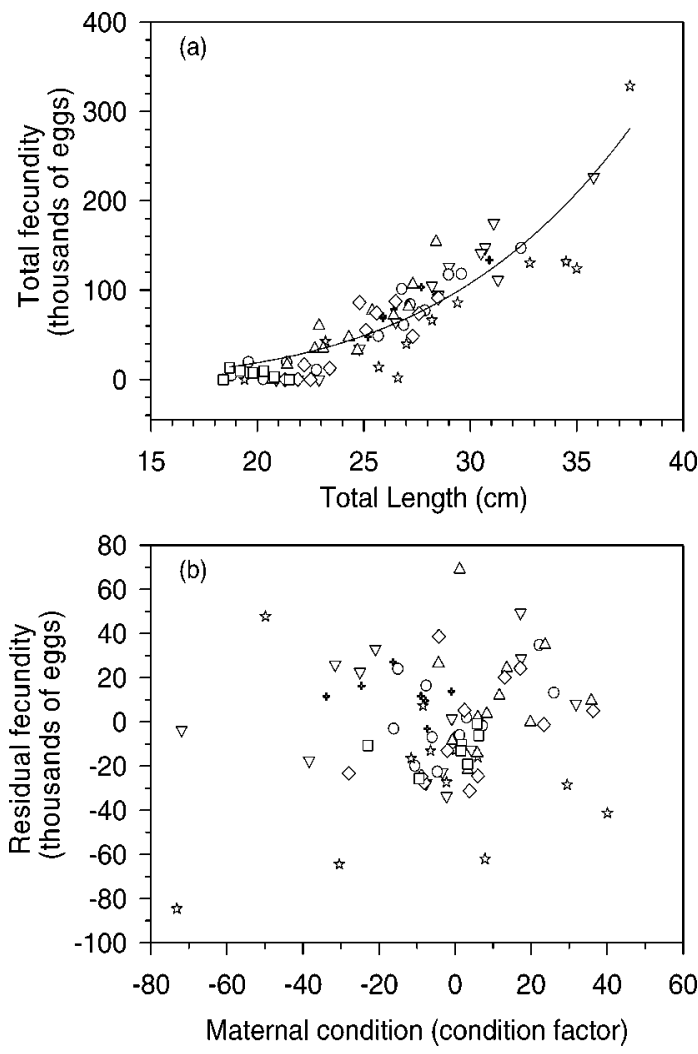

FIgURE 2.-Panel (a) shows total fecundity as a function of total length for 65 prespawning white crappies from seven Ohio study reservoirs in 1999 (see Figure 1 for names and abbreviations). The solid line represents the best fit, from which residual fecundity (observed fecundity - predicted fecundity) could be estimated. Panel (b) depicts the residual fecundity of those 65 fish as a function of the condition index.

cause only 42 adults were sampled in autumn 1998 and none exceeded $21 \mathrm{~cm}$.

The relationship between the CPE of age-2 white crappies and the relative population fecundity was very poor, less than $5 \%$ of the variation in recruitment being explained by both the Ricker $\left(r^{2}=0.04\right.$, Figure 4a) and Beverton and Holt $\left(r^{2}\right.$ $=0.02$, Figure $4 \mathrm{c}$ ) models. The average number of recruits for a given level of spawning stock, which was calculated by using the error term, yielded a considerably higher number of recruits than that predicted by least-squares estimation (Figures $4 \mathrm{a}, \mathrm{c}$ ). Mean ovary quality was uncorrelated to the recruitment residuals for both the Ricker $(r=0.03, P=0.94)$ and Beverton-Holt $(r$ $=0.10, P=0.84$; Figure $4 \mathrm{~b}, \mathrm{~d})$ models. Acton Reservoir, which had the largest positive residual recruitment, had the second highest mean ovary energy density, which was consistent with our hypothesis that high ovary quality might explain higher than expected recruitment. White crappies from Caesar Creek Reservoir, however, had the highest mean ovary energy density among the populations but had a negative residual, which was opposite from our hypothesis.

\section{Discussion}

At the individual level, maternal effects on eggs have been detected for both freshwater and marine fishes. At the population level, however, detection of maternal effects has been limited to populations of haddock (Marshall and Frank 1999) and Atlantic cod in the Barents Sea (Marshall et al. 1999). In this study, we provided evidence for maternal effects on white crappie ovary quality at the individual level. Both maternal length and condition were correlated with white crappie ovary energy density, but because maternal length and condition also covaried, we could not determine which characteristic regulated ovary quality. At the population level, relative population fecundity explained very little of the recruitment variability to age 2 $\left(r^{2}\right.$ range $\left.=0.02-0.04\right)$. Mean ovary quality was unable to explain additional variation because it was unrelated to the residuals from predicted recruitment. Hence, in these seven Ohio reservoirs, incorporating the maternal effects of mean ovary quality did not help to explain variation in recruitment of white crappies to age 2 .

We used energy density to characterize the quality of white crappie eggs, which has been used in at least two previous studies on different species (Keckeis et al. 2000; Ouellet et al. 2001). In both 1999 (seven populations) and 2000 (three of those seven populations), ovary energy density was strongly correlated with maternal length; correlations between ovary energy density and maternal condition were not as strong. Previous studies using egg energy density also have revealed evidence for maternal effects, but whether maternal size or condition is more important remains unclear. For Atlantic cod eggs, energy density increased with Fulton's condition factor but not with maternal size (Ouellet et al. 2001). For nase Chondrostoma nasus eggs, energy density increased with female size, but correlations with female condition were not performed (Keckeis et al. 2000). In general, however, our study supports others that have found measures of egg quality (e.g., egg diameter, dry weight) to be related to either maternal condition (e.g., Chambers and Waiwood 1996; Marteinsdottir and Steinarsson 1998) or size (Beacham and 


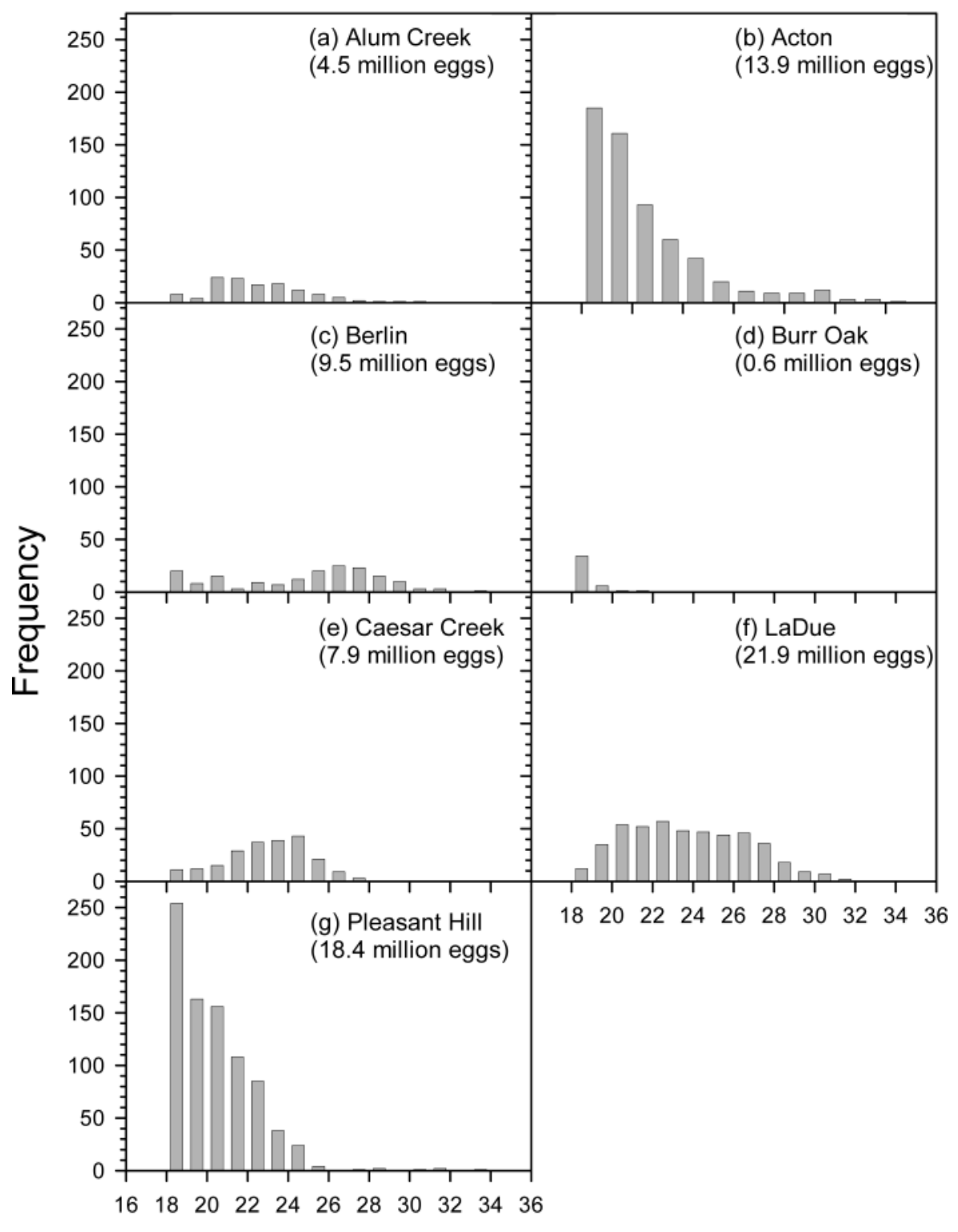

Total length $(\mathrm{cm})$

FIGURE 3.- Total length frequency distributions of white and black crappies sampled in seven Ohio reservoirs in autumn 1998. These distributions were used to estimate relative population fecundity (in parentheses on each panel) for the following spring (i.e., eggs producing the 1999 year-class). One 55-cm adult from Ladue Reservoir was not included in that panel.

Murray 1985; Kjesbu 1989; Johnston and Leggett 2002).

One of the most important findings of our work is that the measure of maternal condition can influence whether or not a maternal effect is detected. Most studies that have evaluated maternal effects on eggs have used a condition factor based on length and weight to measure maternal condition, whereas we used both condition factor and somatic energy density. Although condition factors can be predictive of physiological condition for lean species such as Atlantic cod (Lambert and Dutil 1997), they are not useful for other species, such as clupeids (Strange and Pelton 1987). In our 

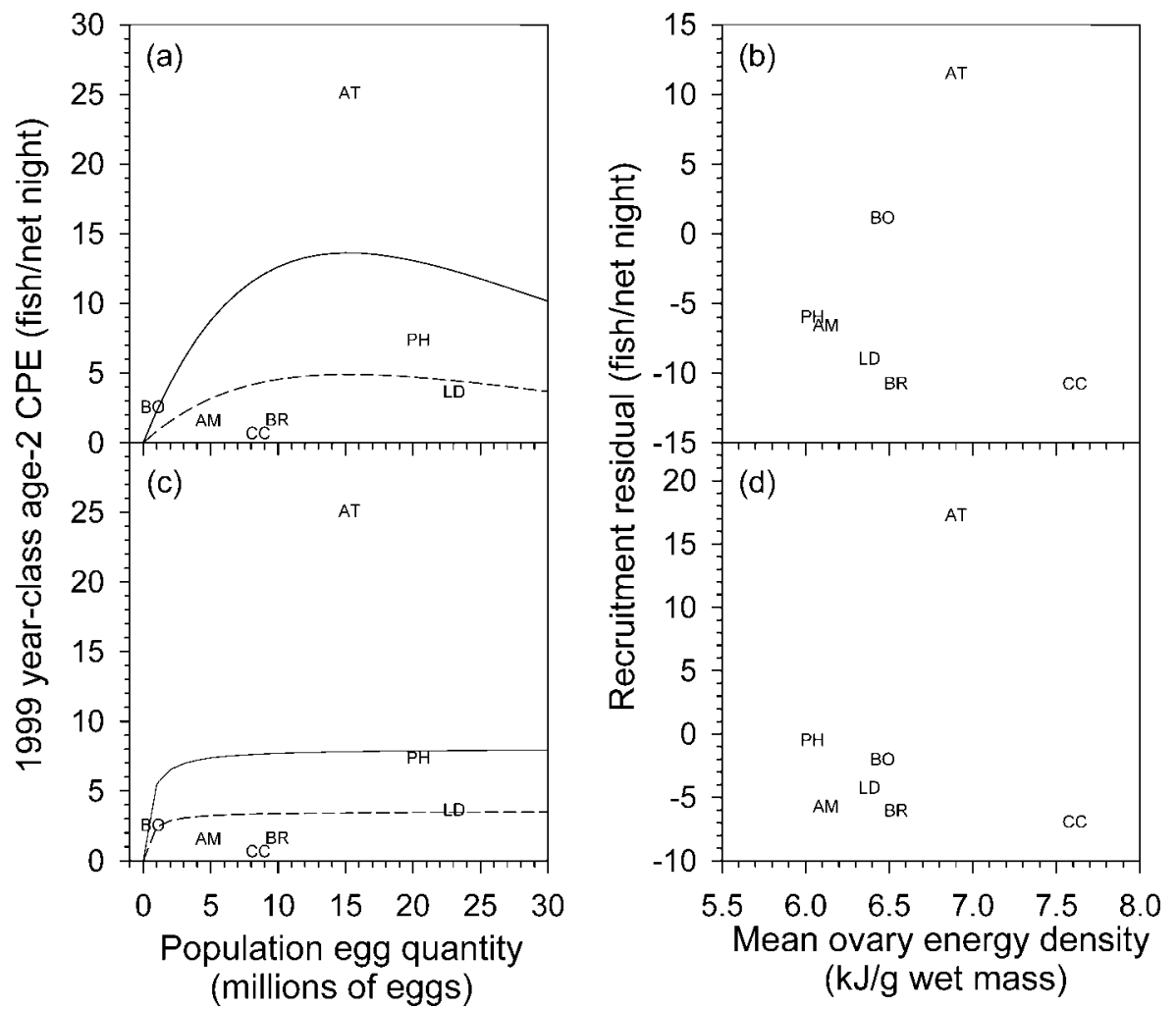

FIGURE 4.- Recruitment or catch per effort (CPE) of age-2 white crappies (autumn 2001 trap-netting in seven Ohio reservoirs) as a function of relative population fecundity is depicted for the (a) Ricker and (c) Beverton and Holt stock-recruit models, where the solid line is the average number of recruits for a given level of spawning stock (i.e., incorporating the model error; $R=S e^{0.89(1-S / 13.53)}$ in panel a; $R=8.05 S /(0.46+S)$ in panel c) and the dashed line is the predicted number of recruits estimated directly from least-squares regression (i.e., not incorporating the model error; $R=S e^{-0.13[1-S /(-2.01])]}$ in panel a; $R=3.55 S /(0.46+S)$ in panel c). For each model, we calculated the residual recruitment as the difference between the observed and predicted average recruitment (solid line), given the relative population fecundity. Residual recruitment (i.e., difference between observed and predicted recruitment) of the same crappies as a function of mean ovary (wet weight) energy density is depicted for the (b) Ricker and (d) Beverton and Holt models. Symbols are as follows: AT = Acton, AM = Alum Creek, BR = Berlin, $\mathrm{BO}=$ Burr Oak, $\mathrm{CC}=$ Caesar Creek, $\mathrm{LD}=$ LaDue, and $\mathrm{PH}=$ Pleasant Hill .

study, condition factor was a significant, though weak, predictor of somatic energy density $\left(r^{2}=\right.$ $0.19 ; P=0.002 ; N=47$ fish). Percent dry weight was a much better predictor of somatic energy density $(\mathrm{kJ} / \mathrm{g}$ of wet soma $=-3.18+32.18[$ dry mass/ wet mass]; $\left.F_{1,45}=220.44, r^{2}=0.83, P<0.0001\right)$, a result that has been found for other species (Hartman and Brandt 1995). Percent dry weight was an even stronger predictor of ovary energy density $(\mathrm{kJ} / \mathrm{g}$ of wet ovary $=-1.16+29.50$ [dry mass/ wet mass]; $\left.F_{1,153}=14779, r^{2}=0.99, P<0.0001\right)$. Because percent dry weight also correlates strongly with lipid percentage in fishes (Flath and Diana 1985), we recommend using percent dry weight for investigators seeking a measure of condition that is relatively quick and inexpensive and more predictive of physiological condition than a condition factor that uses wet mass only.

In 2000, we were able to use both measures of condition to explore relationships with ovary energy density. Condition factor and ovary energy density were positively related to one another in 1999, but not in 2000. Because maternal length was positively correlated with ovary energy density in both years, we would have concluded that maternal size had a greater effect on ovary quality than maternal condition had we not estimated maternal condition with energy density. However, in 2000 there was a strong positive correlation between somatic energy density and ovary energy 
density, suggesting that maternal condition might be having just as great an effect on ovary energy density as maternal size.

The strong correlation between maternal somatic energy density and maternal length in 2000 further complicates our understanding of the mechanism regulating the quality of eggs for white crappies. As white crappies grow to about 15 and $20 \mathrm{~cm}$ TL, they become less gape-limited and undergo an ontogenetic shift in diet from planktivory to piscivory (Ellison 1984; Muoneke et al. 1992). Hence, a larger gape provides the opportunity for larger fishes to consume more energy-rich fish prey and increase their somatic energy density. Regarding maternal effects, we can conclude that large white crappies, which also happen to store more energy per gram of soma than small crappies, tend to produce more energy-rich eggs than small white crappies.

We interpret our results to suggest that large or high-condition females will produce higher quality eggs than their small or poor-condition counterparts during the 6-8 week spawning season. Alternatively, however, our findings could be the result of collecting ovaries that are in different developmental stages because fish of different sizes spawn at different times. Consequently, low energy density of eggs could have been the result of eggs that were not fully yolked because they were not fully developed (i.e., late-spawning fishes). Indeed, large fish spawn earlier than smaller fish in a number of taxa including Atlantic herring Clupea harengus (Ware and Tanasichuk 1989), capelin Mallotus villosus (Carscadden et al. 1997), and largemouth bass Micropterus salmoides (Goodgame and Miranda 1993). Although rarely considered as an important maternal effect, maternal size and its impact on the timing of spawning can be critical for larval survival (e.g., Crecco and Savoy 1985; Bunnell et al. 2003). Hence, if maternal characteristics influence the timing of spawning by white crappies, then maternal effects may indirectly influence larval survival.

For a given size, females with high condition factor were no more fecund than females of low condition factor. Similarly, female white crappies with the highest condition factors in Alabama reservoirs were not the most fecund (Dubuc and DeVries 2002). Although length or size nearly always explains the most variation in fecundity (Blaxter 1969), previous studies with Atlantic cod and haddock on the Scotian shelf have found that additional variation in fecundity can be explained by maternal condition (Kjesbu et al. 1991; Lambert and Dutil 2000; Blanchard et al. 2003). Koops et al. (2004), however, noted that the positive effect of condition on fecundity could be an artifact of how the analyses are conducted. Specifically, if body mass explains more of the variation in fecundity than fish length, then analyses should begin by determining the effect of body mass on fecundity and then determine whether a measure of condition explains additional variation (Koops et al. 2004). In our study, fish total length $\left(r^{2}=\right.$ $0.91)$ explained more of the variation in fecundity than body mass $\left(r^{2}=0.84\right)$, meaning that we evaluated whether maternal condition influenced fecundity with the correct residual. In the end, however, a more definitive test would have been to regress residual white crappie fecundity with somatic energy density because somatic energy density is a better measure of physiological condition than condition factor.

After determining maternal effects on ovary energy density, we then sought to determine whether population measures of the quantity or quality of eggs produced were related to variation in recruitment to age 2. Although neither model explained much variation in the data, the dome-shaped Ricker curve may be more appropriate because the highest recruitment occurred at intermediate levels of relative population fecundity (i.e., Acton Reservoir) and then lower recruitment occurred as relative population fecundity increased to higher levels (i.e., Pleasant Hill and LaDue Reservoirs). The Ricker model also was chosen to explain recruitment variability within four southeastern U.S. reservoirs (Allen and Miranda 1998). We had hypothesized that the residuals from the stock-recruit models could be explained by considering variation in mean egg quality. No correlations existed, however.

Some caveats regarding our population-level analyses should be noted. First, our stock-recruit models included several populations in 1 year, rather than the conventional approach of including several years of one population. The advantages to our approach are that we could complete our study in a relatively short time and avoid problems associated with autocorrelated time series data in conventional analyses (Walters 1985). Second, our sample size $(N=7)$ may have limited our ability to detect the effect of ovary quality on white crappie recruitment to age 2 (i.e., we may have committed a type II error). Third, our estimates of adult and age-2 CPE are based on sampling gear catchability that could differ across reservoirs. In our view, this is unlikely because we fished the nets 
in similar types of locations (i.e., depth, proximity to channel) in all reservoirs and because our reservoirs were largely similar in their morphology and mean depth (see Table 1, with Caesar Creek Reservoir being the one outlier). In the end, we acknowledge that future studies that are able to include several years of data in one system may have a greater likelihood of determining the effect of ovary quality on recruitment, if indeed the effect exists.

Despite our inability to detect the effect of egg quality on white crappie recruitment, recent studies suggest that recruitment is indeed set in early life (i.e., by the larval stage). Much of this evidence rests on reservoir hydrology, which correlates with recruitment in reservoirs in the Southeast and Midwest (Mitzner 1981; Beam 1983; McDonough and Buchanan 1991; Maceina and Stimpert 1998). High water levels during the spawning season are speculated to increase recruitment by increasing spawning habitat and subsequent larval production (Mitzner 1981; Beam 1983). In addition, high water levels (or short retention times) before spawning are correlated with high recruitment (Maceina and Stimpert 1998; Sammons et al. 2002; Maceina 2003), perhaps by influencing the feeding environment (i.e., food availability or turbidity, which may influence feeding efficiency) for age-0 crappies in the limnetic area (Maceina 2003). In addition, larval densities were strongly predictive of age- $1 \mathrm{CPE}$ across 5 years in Normandy Reservoir, Tennessee (Sammons and Bettoli 1998). Taken together, these results suggest that factors early in life (i.e., prespawning, spawning, and larval period) may set crappie recruitment in reservoirs. At the northern edge of the white crappie range (including Ohio), however, cold winter temperatures may limit survival during the first winter of life (McCollum et al. 2003), which in turn, may result in recruitment being set considerably later than the larval period.

Although our study revealed that the characteristics of eggs alone were insufficient to predict recruitment variability of white crappies across Ohio reservoirs, consideration of the characteristics of the adult female population with other potentially important factors (e.g., hydrology, winter temperatures) should improve our current understanding of recruitment variation. To further explore maternal effects on recruitment, data on maternal condition and maternal size can be culled from ongoing population surveys by biologists and fishery managers. For maternal condition, we recommend estimating either percent dry weight or removing the liver to calculate the hepatosomatic index (mass of liver/total fish mass; Marshall et al. 1999) on a subsample of fishes across a representative size distribution of the population. Both of these measures provide an estimate of the somatic reserves and physiological condition and are much less costly than estimating energy density or percent lipids. Likewise, ovary quality of prespawning fishes can also be coarsely estimated using percent dry weight. Although these measures all require killing the fish, many surveys already sacrifice a subsample of fish for otolith collection and age estimation. In conclusion, because this and previous studies continue to document maternal effects among individuals, we encourage future studies to take the next step and begin testing the hypothesis that maternal effects influence population-level responses such as recruitment.

\section{Acknowledgments}

Scott Hale has been an invaluable asset to our investigations of crappie populations in Ohio reservoirs. J. Fricke, J. Pyzoha, S. Thomas, J. Denlinger, D. Glover, R. Ginsberg, D. Gloeckner, M. Haugen, A. Iarussi, C. Hutt, E. Kohagen, B. Lutmerding, H. McLean, S. Miehls, A. Peer, J. Ritchie, M. Schmidt, A. Spencer, M. Thomas, M. Tomasi, J. Williams, and the Ohio Department of Natural Resources, Division of Wildlife provided assistance with fieldwork and laboratory processing. S. Hale, S. Ibargüen, T. Johnston, E. Marschall, D. Pereira, S. Sammons, members of Thomas Miller's Quantitative Fisheries Ecology Laboratory, and an anonymous reviewer provided several helpful comments to this manuscript. This research was funded by Federal Aid in Sport Fish Restoration Project F-69-P, administered jointly by U.S. Fish and Wildlife Service and Ohio Department of Natural Resources, Division of Wildlife and the Department of Evolution, Ecology, and Organismal Biology at Ohio State University.

\section{References}

Allen, M. S., and L. E. Miranda. 1998. An age-structured model for erratic crappie fisheries. Ecological Modelling 107:289-303.

Beacham, T. D., and C. B. Murray. 1985. Effect of female body size, egg size, and water temperature on developmental biology of chum salmon (Oncorhynchus keta) from the Nitinat River, British Columbia. Canadian Journal of Fisheries and Aquatic Sciences 42:1755-1765.

Beam, J. H. 1983. The effect of annual water level management on population trends of white crappie in Elk City Reservoir, Kansas. North American Journal of Fisheries Management 2:34-40. 
Blanchard, J. L., K. T. Frank, J. E. Simon. 2003. Effects of condition on fecundity and total egg production of east Scotian Shelf haddock (Melanogrammus aeglefinus). Canadian Journal of Fisheries and Aquatic Sciences 60:321-332.

Blaxter, J. H. S. 1969. Development: eggs and larvae. Pages 177-252 in W. S. Hoar and D. J. Randall, editors. Fish physiology: reproduction and growth, bioluminescence, pigments, and poisons, Volume III. Academic Press, New York.

Bunnell, D. B., M. J. Gonzalez, and R. A. Stein. 2003. Zooplankton influences growth, but not survival, of first-feeding Pomoxis spp. larvae. Canadian Journal of Fisheries and Aquatic Sciences 60:1314-1323.

Carscadden, J., B. S. Nakashima, and K. T. Frank. 1997. Effects of fish length and temperature on the timing of peak spawning in capelin (Mallotus villosus). Canadian Journal of Fisheries and Aquatic Sciences 54:781-787.

Chambers, R. C., and K. G. Waiwood. 1996. Maternal and seasonal differences in egg sizes and spawning characteristics of captive Atlantic cod, Gadus morhua. Canadian Journal of Fisheries and Aquatic Sciences 53:1986-2003.

Colvin, M. A., and F. W. Vasey. 1986. A method of qualitatively assessing white crappie populations in Missouri reservoirs. Pages 79-85 in G. E. Hall and M. J. Van Den Avyle, editors. Reservoir fisheries management: strategies for the 80's. American Fisheries Society, Southern Division, Reservoir Committee, Bethesda, Maryland.

Colvin, M. A. 1991. Population characteristics and angler harvest of white crappie in four large Missouri reservoirs. North American Journal of Fisheries Management 11:572-584.

Crecco, V. A., and T. F. Savoy. 1985. Effects of biotic and abiotic factors on growth and relative survival of young American shad, Alosa sapidissima, in the Connecticut River. Canadian Journal of Fisheries and Aquatic Sciences 42:1640-1648.

DeVries, D. R., and R. V. Frie. 1996. Determination of age and growth. Pages 483-512 in B. R. Murphy and D. W. Willis, editors. Fisheries techniques, 2nd edition. American Fisheries Society, Bethesda, Maryland.

Dubuc, R. A., and D. R. DeVries. 2002. An exploration of factors influencing crappie early life history in three Alabama impoundments. Transactions of the American Fisheries Society 131:476-491.

Ellison, D. G. 1984. Trophic dynamics of a Nebraska black crappie and white crappie population. North American Journal of Fisheries Management 4:355364.

Flath, L. E., and J. S. Diana. 1985. Seasonal energy dynamics of the alewife in southeastern Lake Michigan. Transactions of the American Fisheries Society $114: 328-337$.

Goodgame, L. S., and L. E. Miranda. 1993. Early growth and survival of age-0 largemouth bass in relation to parental size and swim-up time. Transactions of the American Fisheries Society 122:131-138.

Hartman, K. J., and S. B. Brandt. 1995. Estimating en- ergy density of fish. Transactions of the American Fisheries Society 124:347-355.

Henderson, B. A., and S. J. Nepszy. 1994. Reproductive tactics of walleye (Stizostedion vitreum) in Lake Erie. Canadian Journal of Fisheries and Aquatic Sciences 51:986-997.

Hilborn, R., and C. J. Walters. 1992. Quantitative fisheries stock assessment. Chapman and Hall, New York.

Johnston, T. A., and W. C. Leggett. 2002. Maternal and environmental gradients in the egg size of an iteroparous fish. Ecology 83:1777-1791.

Keckeis, H., E. Bauer-Nemeschkal, V. V. Menshutkin, H. L. Nemeschkal, and E. Kamler. 2000. Effects of female attributes and egg properties on offspring viability in a rheophilic cyprinid, Chondrostoma nasus. Canadian Journal of Fisheries and Aquatic Sciences 57:789-796.

Kjesbu, O. S. 1989. The spawning activity of cod, Gadus morhua L. Journal of Fish Biology 34:195-206.

Kjesbu, O. S., J. Klungsøyr, H. Kryvi, P. R. Witthames, and M. Greer Walker. 1991. Fecundity, atresia, and egg size of captive Atlantic cod (Gadus morhua) in relation to proximate body composition. Canadian Journal of Fisheries and Aquatic Sciences 48:23332343.

Koops, M. A., J. A. Hutchings, and T. A. McIntyre. 2004. Testing hypotheses about fecundity, body size, and maternal condition in fishes. Fish and Fisheries 5: $120-130$.

Laine, P., and M. Rajasilta. 1999. The hatching success of Baltic herring eggs and its relation to female condition. Journal of Experimental Marine Biology and Ecology 237:61-73.

Lambert, Y., and J. D. Dutil. 1997. Can simple condition indices be used to monitor and quantify seasonal changes in the energy reserves of Atlantic cod ( $\mathrm{Ga}$ dus morhua)? Canadian Journal of Fisheries and Aquatic Sciences 54(Supplement 1):104-112.

Lambert, Y., and J. D. Dutil. 2000. Energetic consequences of reproduction in Atlantic cod (Gadus morhua) in relation to spawning level of somatic energy reserves. Canadian Journal of Fisheries and Aquatic Sciences 57:815-825.

Maceina, M. J., and M. R. Stimpert. 1998. Relations between reservoir hydrology and crappie recruitment in Alabama. North American Journal of Fisheries Management 18:104-113.

Maceina, M. J. 2003. Verification of the influence of hydrologic factors on crappie recruitment in Alabama reservoirs. North American Journal of Fisheries Management 23:470-480.

Marshall, C. T., and K. T. Frank. 1999. The effect of interannual variation in growth and condition on haddock recruitment. Canadian Journal of Fisheries and Aquatic Sciences 56:347-355.

Marshall, C. T., N. A. Yaragina, Y. Lambert, and O. S. Kjesbu. 1999. Total lipid energy as a proxy for total egg production by fish stocks. Nature (London) 402: 288-290.

Marteinsdottir, G., and A. Steinarsson. 1998. Maternal influence on the size and viability of Iceland cod 
Gadus morhua eggs and larvae. Journal of Fish Biology 52:1241-1258.

McCollum, A. B., D. B. Bunnell, and R. A. Stein. 2003. Cold, northern winters: the importance of temperature to survival of age-0 white crappie. Transactions of the American Fisheries Society 132:977987.

McDonough, T. A., and J. P. Buchanan. 1991. Factors affecting abundance of white crappies in Chickamauga Reservoir, Tennessee, 1970-1989. North American Journal of Fisheries Management 11: 513-524.

Mitzner, L. 1981. Influence of floodwater storage on abundance of juvenile crappie and subsequent harvest at Lake Rathbun, Iowa. North American Journal of Fisheries Management 1:46-50.

Muoneke, M. I., C. C. Henry, O. E. Maughan. 1992. Population-structure and food-habits of white crappie Pomoxis annularis Rafinesque in a turbid Oklahoma reservoir. Journal of Fish Biology 41: 647-654.

Ouellet, P., Y. Lambert, and I. Berube. 2001. Cod egg characteristics and viability in relation to low temperature and maternal nutritional condition. ICES Journal of Marine Science 58:672-686.

Parr Instrument Co. 1993. 1672 Thermometer operating instruction manual: technical manual 283MM. Parr Instrument Co., Moline, Illinois.

Phillips, A. M. 1969. Nutrition, digestion, and energy utilization. Pages 391-432 in W. S. Hoar and D. J. Randall, editors. Fish physiology, volume 1. Academic Press, New York.
Rand, P. S., B. F. Lantry, R. O'Gorman, R. W. Owens, and D. J. Stewart. 1994. Energy density and size of pelagic prey fishes in Lake Ontario, 1978-1990: implications for salmonine energetics. Transactions of the American Fisheries Society 123:519-534.

SAS Institute. 1999. SAS/STAT user's guide, version 8. SAS Institute Inc., Cary, North Carolina.

Sammons, S. M., and P. W. Bettoli. 1998. Larval sampling as a fisheries management tool: early detection of year-class strength. North American Journal of Fisheries Management 18:137-143.

Sammons, S. M., P. W. Bettoli, D. A. Isermann, and T. N. Churchill. 2002. Recruitment variation of crappies in response to hydrology of Tennessee reservoirs. North American Journal of Fisheries Management 22:1393-1398.

Siefert, R. E. 1968. Reproductive behavior, incubation, and mortality of eggs, and postlarval food selection in the white crappie. Transactions of the American Fisheries Society 97:252-259.

Sprugel, D. G. 1983. Correcting for bias in log-transformed allometric equations. Ecology 64:209-210.

Strange, R. J., and J. C. Pelton. 1987. Nutrient content of clupeid forage fishes. Transactions of the American Fisheries Society 116:60-66.

Walters, C. J. 1985. Bias in the estimation of functional relationships from time-series data. Canadian Journal of Fisheries and Aquatic Sciences 42:147-149.

Ware, D. M., and R. W. Tanasichuk. 1989. Biological basis of maturation and spawning waves in Pacific herring. Canadian Journal of Fisheries and Aquatic Sciences 46:1776-1784. 